\title{
EFEKTIFITAS PENDEKATAN REALISTIK \\ DALAM MENINGKATKAN KEMAMPUAN PENALARAN MATEMATIK SISWA DI SEKOLAH MENENGAH ATAS NEGERI 1 TEMBILAHAN, INHIL, RIAU
}

\author{
Herwati Ahmad \\ Guru SMAN 1 Tembilahan, Inhil, Riau \\ Email: herwatibintiahmad@yahoo.com
}

\begin{abstract}
Abstrak
Penelitian ini bertujuan untuk mengetahui efektifitas pendekatan realistik dalam meningkatkan kemampuan penalaran Matematik (penalaran analogi dan generalisasi Matematik). Subjek penelitian ini melibatkan sebanyak 69 siswa kelas 10 di Sekolah Menengah Atas Negeri 1 Tembilahan, Inhil, Riau. Sebanyak 35 siswa (19 laki-laki\& 16 perempuan) sebagai kelompok eksperimen yang mengikuti pembelajaran dengan menggunakan pendekatan realistiksedangkan 34 siswa (19 laki-laki\& 15 perempuan) sebagai kelompok kontrol yang mengikuti pembelajaran dengan pendekatan tanpa realistik. Pengumpulan data dilakukan sebanyak dua kali yaitu pada ujian pretes dan postes. Pelaksanaan penelitian dilaksanakan selama delapanrata-rataggu. Kemampuan penalaran Matematik diukur dengan menggunakan ujian tertulis yang terdiri dari 16 item yaitu 8 item penalaran analogi Matematik dan 8 item penalaran generalisasi Matematik. Hasil penelitian menunjukkan peningkatan kemampuan penalaran analogi dan generalisasi Matematik dengan menggunakan pendekatan realistik. Kemampuan penalaran Matematik lebih tinggi apabila menggunakan pendekatan realistik dibandingkan dengan tanpa realistik. Pendekatan realistik memberikan kesempatan kepada siswa untuk menjadi lebih aktif dalam pengajaran dan pembelajaran Matematika. Pembelajaran dengan menggunakan pendekatan realistik memberikan kesan yang baik terhadap diri siswa. Siswa menjadi lebih positif dalam pembelajaran dan mencari sendiri konsep Matematika dan bukan lagi merupakan pemberitahuan dari guru. Siswa itu sendiri yang aktif mengkonstruksi pengetahuannya. Siswa merasa diberi kesempatan untuk mengeksplor pemikirannya. Pendekatan realistik menjadikan pembelajaran berpusatkan siswa sehingga siswa merasa senang dalam pembelajaran Matematika dan ini secara tidak langsung dapat meningkatkan kemampuan Matematika kepada tahap yang lebih tinggi.
\end{abstract}

Kata Kunci: Analogi, Generalisasi, Kemampuan Matematika, Pendekatan realistik.

\begin{abstract}
This study aims to determine the effectiveness of realistic approach in improving the ability of matematikaematical reasoning (analogical reasoning and matematikaematical generalization). The subject of this research involves 69 students of 10th grade in Tembilahan 1st State High School, Inhil, Riau. There were 35 students (19 men \& 16 women) as experimental group that followed the learning by using realistic approach whereas 34 students (19 men \& 15 women) as control group that followed lesson with unrealistic approach. Data collection is done twice on the pretest and posttest. The implementation of the research was carried out for eight weeks. Matematikaematical reasoning abilities are measured using a written exam consisting of 16 items, namely 8 Matematikaematical analogue reasoning items and 8 Matematikaematical generalization-reasoning items. The result of the research shows improvement of analogy reasoning ability and matematikaematical generalization by using realistic approach. Matematikaematical reasoning ability is higher when using a realistic approach than without realistic. The realistic approach provides an opportunity for students to become more active in teaching
\end{abstract}


and learning Matematikaematics. Learning by using a realistic approach gives a good impression on the student self. Students become more positive in learning, seek their own Matematika concepts, and are no longer a notice from the teacher. The student actively constructs his knowledge. Students feel given the opportunity to explore their thoughts. The realistic approach makes student-centered learning so that students feel happy in learning Matematikaematics and this can indirectly improve the ability of Matematikaematics to a higher stage.

Keywords: Analogy, Generalization, Matematikaematical Ability, Realistic Approach.

\section{Pendahuluan}

Matematika suatu disiplin ilmu yang sangat penting dalam kehidupan manusia (Nik, 2008). Dan merupakan dasar kepada semua bidang disiplin ilmu (Yuliani, 2006). Pembelajaran matematika penting untuk mendukung kehidupan masa depan siswa. Namun sistem dan metode pengajaran yang dilakukan oleh guru, sebahagian besar masih menggunakan pendekatan berpusatkan guru (Isjoni, 2007). Guru yang aktif menstransfer ilmu kepada siswa, guru mengamalkan paradigma lama yaitu menggunakan pendekatan tradisional (Zulkardi, 2002). Padahal siswa tidak seharusnya pasif dan hanya memberikan penjelasan terhadap pertanyaan guru. Sebaliknya, siswa sendiri yang seharusnya mengeksplor ide-ide dan mencari kesempatan untuk belajar dan bertanggungjawab terhadap pembelajaran (Arsaythamby \& Hashim, 2009). Siswa yang aktif memungkinkan pengembangan penalaran matematika. Penalaran sangat penting dimiliki oleh siswa, baik untuk pembelajaran matematika itu sendiri maupun untuk kegunaan dalam kehidupan sehari-hari.

Penalaran tidak hanya diperlukan oleh siswa dalam mempelajari matematika, tetapi menjadi penting untuk penyelesaian masalah dalam kehidupan sehari-hari yang dihadapi siswa (Shadiq, 2004, Agustus). Aktivitas matematika berkaitan dengan pemikiran (Kania, 2009). Sehingga dalam matematika, penalaran merupakan suatu alat untuk mengkonstruksi pengetahuan (Suharta, 2003). Di samping itu penalaran merupakan bagian yang penting dalam penyelesaian masalah matematika (Diezmann, 2004).

Begitu pentingnya penalaran dalam pembelajaran matematika, maka pendekatan dalam pembelajaran dan pengajaran matematika perlu perubahan (Zulkardi, Nieveen, van den Akker \& dande Lange, 2002). Djaali (2008, Juli 25) menyatakan bahwa cara pengajaran matematika di sekolah yang ada di Indonesia harus dirubah karena menjadi penyebab utama ketidaklulusan siswa dalam ujian nasional. Matematika harus diberikan dengan cara yang menyenangkan sehingga lebih mudah dipahami siswa. Edy (2008, Juli 25) menambahkan, 
guru dalam mengajar harus berusaha menerapkan metode pengajaran matematika yang baru. Pengajaran matematika harus diperbaiki agar menyenangkan bagi siswa, pengajaran harus dimulai dengan apa yang dipahami oleh siswa. Perubahan proses pembelajaran matematika yang menyenangkan bagi siswa harus menjadi utama (Saodi, 2008).

Menyadari betapa pentingnya faktor pendekatan dalam pembelajaran, maka penelitian ini mencoba memberikan sesuatu alternatif pendekatan dalam pembelajaran. Menurut Zulkardi dan Nieveen (2001, Agustus) pendekatan yang memberikan harapan terhadap pembelajaran Matematika di Indonesia adalah Realistic Matematics Education (RME). Demikian juga menurut Zulkardi, Nieveen, van den Akker, dande Lange (2002) salah satu pendekatan yang menjanjikan terhadap pengajaran dan pembelajaran matematika adalah $R M E$. $R M E$ merupakan pendekatan dalam pendidikan matematika yang menjadi dasarnya adalah realistik dan dapat dijadikan sebagai salah satu metode pembelajaran matematika (Novikasari, 2007).

$R M E$ telah diterapkan oleh beberapa negara yang ada dunia seperti: Jerman, Inggris, Denmark, Portugal, Spanyol, Jepang, Afrika Selatan, Malaysia, Brasil, dan Amerika (de Lange, 1998). $R M E$ sebuah pendekatan dalam pendidikan matematika yang dikembangkan di Belanda (Netherlands), tetapi penelitian penjelajahan melaporkan bahwa pendekatan ini tidak mustahil untuk digunakan di Indonesia (Fauzan, Slettenhar, \& Plomp, 2002). Di Indonesia $R M E$ dikenal sebagai Pendidikan Matematika Realistik Indonesia (PMRI) telah dicobakan melalui suatu penelitian dan proyek percobaan di Pulau Jawa. Sedangkan di Pulau Sumatera khususnya RIAU, RME belum dicobakan.

RME di Indonesia dimulai pertengahan 1990-an ini merupakan percobaan kedua setelah pergerakan pertama untuk matematika tradisional ke matematika Modern (1975 1990) adalah gagal (Hadi, 2012, Juli). Lebih lanjut Hadi (2012, Juli) menyatakan bahwa sekelompok ahli matematika dan pendidik matematika bersusah hati melihat keadaan ini, mereka menginginkan perubahan pendidikan matematika di Indonesia. Melalui musyawarah akhirnya disimpulkan untuk memilih $R M E$ sebagai konsep dasar untuk perkembangan pengajaran dan pembelajaran matematika di Indonesia.

Hasil penelitian dan proyek percobaan merekomendasikan bahwa pembelajaran $R M E$ dapat dilaksanakan di sekolah yang ada di Indonesia dan dapat dilanjutkan kepada kelas yang lebih tinggi (Zulkardi, Nieveen, van den Akker \& de Lange, 2002). Sembiring, Sutarto Hadi, dan Dolk (2008) menyatakan bahwa $R M E$ yang kemudian diadaptasi menjadi PMRI, dimana didalamnya dilakukan pengembangan isi kandungan pembelajaran memberikan hasil bahwa sebahagian besar siswa dan guru menyambut dengan positif pembelajaran tersebut. Salah satu 
pendekatan yang berpeluang besar bagi peningkatan hasil belajar matematika dan diharapkan dapat meningkatkan kemampuan siswa dalam penyelesaian masalah matematika adalah pendekatan realistik (Darhim, 2004). Konsep Hans Freudenthal tentang matematika dan pendidikan matematika masih sah, walaupun telah 20 tahun dikembangkan (Erich, 2005).

\section{Pernyataan Masalah}

Masalah yang dihadapi pendidikan di Indonesia pada saat ini adalah krisis paradigma berupa jurang dan ketidaksesuaian antara tujuan yang inginkan dengan metode pengajaran yang berlaku. Pengajaran hanya mengarahkan siswa kepada penguasaan informasi yang akhirnya menjadikan siswahanya memiliki pengetahuan jangka pendek, sementara kehidupan di masa yang akan datang menuntut siswa mampu melakukan pemecahan baru secara inovatif (Sumadi, 2005). Pendidikan di Indonesia hanya menekankan penguasaan pengetahuan secara teoritis dan kurang menekankan penerapan dalam kehidupan sehari-hari. Sehingga kualitas pendidikan masih rendah, khususnya dalam kualitas pembelajaran matematika (Soedjadi, 2001, Februari).

Menurut Zulkardi (2002) pengajaran matematika yang dilaksanakan oleh guru kurang berkesan dan pendekatan dalam pembelajaran tidak mampu mengoptimalkan kemampuan siswa sehingga kemampuan matematika siswa semakin rendah. Kemampuan matematika siswa secara internasional menurut TIMSS (Trends in Internasional Matematikaematics and Science Study), siswa Indonesia berada pada tahap paling rendah (Sembiring, Hadi \& Dolk, 2008; Kamaliyah, Zulkardi \& Darmawijoyo, 2013). Hasil TIMSS tahun 2003 Indonesia berada pada peringkat ke-34 dari50 negara dengan skor rata-rata 411, tahun 2007 peringkat 36 dari 49 negara dengan skor rata-rata 397 dan tahun 2011 peringkat 38 dari 42 negara dengan skorrata-rata 386. Kesimpulannya: (1) kemampuan matematika siswa Indonesia di bawah skor Internasional yaitu 500; (2) siswa Indonesia hanya mampu menjawab soal-soal dalam kategori rendah, dan hampir tidak ada yang dapat menjawab soal-soal yang menuntut pemikiran tingkat tinggi.

Kemampuan matematika siswa Indonesia secara internasional adalah rendah begitupula kemampuan matematika siswa Indonesia dalam ujian nasional dibawah 4.25 dimana standar nilai adalah 5.5 (Djaali, 2008, Julai 25). Banyak siswa yang tidak lulus karena nilai mata pelajaran matematika jelek. Mata pelajaran yang tersukar bagi siswa adalah matematika (Budiyono, 2010). Menurut Nuh (2013, Mei 23) persentase kelulusan dalam ujian nasional tahun 2013 mengalami penurunan sebanyak $0.02 \%$ dibandingkan tahun 
2012.Faktor penyebab ketidaklulusan siswa karena rata-rata dibawah standar (rata-rata 5.5). Sebanyak 69.94\% (5.301 siswa) dari total ketidaklulusan adalah dikarenakan rata-rata yang diperoleh siswa tidak mencapai standar, sedangkan 30.06\% (2.278 siswa) dikarenakan ada satu ataupun lebih mata pelajaran yang kurang dari 4. Mata pelajaran yang menjadi masalah bagi siswa adalah Matematika.

Matematika masih menjadi penyebab ketidaklulusan siswa pada ujian nasional. Ketidakberhasilan siswa pada matematika karena sejumlah siswa gagal menguasai dengan baik konsep matematika yaitu siswa kurang menggunakan penalaran yang logik dalam menyelesaikan soal-soal atau persoalan matematika yang diberikan (Wahyuddin, 1999). Proses pembelajaran kurang mendorong siswa untuk mengembangkan penalaran (Wina, 2006). Sebagian besar pembelajaran matematika belum terfokus pada pengembangan penalaran matematika (Mulliset al., 2000).

Pembelajaran matematika kurang mendorong siswa berinteraksi dengan sesama siswa dalam belajar, dan kurang mendorong siswa menggunakan penalaran mengakibatkan hasil belajar belum menggembirakan (Permana \& Sumarmo, 2007). Padahal pembelajaran yang memberikan kesempatan kepada siswa untuk mengembangkan penalaran dan pemecahan masalah dapat menjadikan prestasi siswa lebih tinggi (Saragih, 2007). Salah satu kemampuan yang erat kaitannya dengan hasil belajar adalah berpikir logik (penalaran), yaitu kemampuan menemukan suatu kebenaran berdasarkan aturan, pola atau logika tertentu (Suriasumantri, 2007).

Untuk menguasai konsep matematika diperlukan kemampuan khusus. Penalaran adalah kemampuan yang digunakan dalam mengajar dan belajar matematika (Mofidi, Amiripour, dan Zadeh (2012). Tetapi Mulliset al. (2000) dan Herman (2007) menyatakan bahwa kemampuan penalaran siswa sangat rendah. Numendal (dalam Matlin, 1994) menyatakan bahwa masih ada siswa yang mengalami kesukaran dalam mengembangkan penalarannya. Penyelidikan empiris menunjukkan bahwa siswa miskin dalam penalaran matematika (Heinze \& Kwak, 2002).

Demikian juga, penalaran analogi matematika masih kurang berkembang (Ondi \& Siti, 2009). Masalah ini dapat dilihat dimana siswa tidak mempunyai kemampuan untuk mengubah masalah kontekstual menjadi model matematika yang sesuai. Begitu juga kemampuan siswa dalam menterjemahkan suatu masalah ke dalam model matematika masih rendah (Kadir, 2009, Desember). Seringkali dijumpai pada saat pembelajaran berlangsung, para siswa mengalami kesulitan untuk menyelesaikan soal-soal yang berhubungan dengan kehidupan sehari-hari yang memerlukan penggunaan matematika dan menyusunnya ke dalam 
sebuah model matematika (Hasratuddin, 2010). Salah satu aspek kesulitan siswa membuat model adalah interfase diantara masalah dunia nyata dengan model matematika dan sebaliknya transisi model matematika kepada dunia nyata (Crouch \& Haines, 2004). Siswa mengalami kesulitan untuk menciptakan suatu hubungan antara realita dan matematika, untuk menyederhanakan dan penstrukturan realita dan masalah yang memerlukan pemecahan matematika (Maas, 2006). Siswa juga mengalami kesulitan dalam proses: (1) merumuskan masalah dalam kehidupan sehari-hari ke dalam model matematika, seperti menerjemahkankan konteks realita ke dalam model matematika, pemahaman mengenai struktur matematika (termasuk keteraturan, kaitan, dan pola) dalam masalah, (2) menilai kewajaran dari pemecahan matematika dalam konteks masalah dunia nyata (Sri, Hartono \& Putri, 2013). Padahal salah satu tujuan paling penting dari pendidikan matematika adalah membuat siswa mempunyai pemahaman mengenai nilai model matematika (Tekin, Kula, Hidiroglu, Guzel, \& Ugurel, 2011, Juli).

Pendekatan pembelajaran yang digunakan selama ini tidak banyak melibatkan siswa, terutama dalam penemuan konsep matematika (Somakin, 2007, Nopember). Sehingga siswa kurang mengusai konsep matematika (Leonard, 2008). Konsep yang diterima siswa berasal dari guru. Proses pembelajaran matematika masih menekankan penyerapan pengetahuan. Padahal tuntutan dunia global masa yang akan datang justru pada pemanfaatan matematika dalam kehidupan sehari-hari (Iwan Pranoto, 2011, Januari 31).

Kemampuan siswa dalam penerapan matematika rendah dan banyak siswa mengalami kesukaran dalam menerapkan matematika dalam kehidupan sehari-hari (Jenings \& Dunne, 1999; Wina, 2006; Ondi, 2008). Siswa tidak mempunyai kemampuan dalam menggunakan pertimbangan-pertimbangan realistik ketika memecahkan masalah-masalah realistik (Cooper \& Harries, 2002).

\section{Tinjauan Teoritis}

\section{Penalaran Matematika}

Penalaran matematika meliputi pengertian hubungan abstrak (seperti: persamaan, perbandingan, integral) yang dapat terlihat pada konteks yang berbeda (Lindsey, Osnat, \& Keit, 2007). Penalaran didefinsikan sebagai perbuatan menggunakan fikiran untuk memperoleh kesimpulan dari beberapa premis (Mofidi, Amiripour, \& Zadeh, 2012). Penalaran merupakan suatu proses berfikir dalam mencapai suatu kesimpulan yang berupa 
ilmu pengetahuan (Jujun S. Suriasumantri, 2007). Penalaran merupakan kemampuan dasar dari matematika yang diperlukan untuk beberapa tujuan dalam memahami konsep matematika, menggunakan ide-ide dan prosedur matematika secara fleksibel, dan untuk membangun kembali pengetahuan matematika (Brodie, 2010). Penalaran matematika merupakan alat yang penting untuk memperoleh konsep matematika (Lee, Kim, GwiSoo Na, Han, \& Song, 2007). Penalaran merupakan pusat matematika sebagai suatu disiplin ilmu dan mendasari pembelajaran matematika (Diezman, Watters, \& English, 2002).

Menurut Sumarmo (2010), penalaran dapat dibedakan menjadi penalaran induktif dan penalaran deduktif. Penalaran induktif didefinisikan sebagai sebuah kesimpulan umum dari contoh tertentu (Mofidi, Amiripour \& Zadeh, 2012). Penalaran induktif berkaitan dengan generalisasi sebagai bagian yang melibatkan pencarian pola dari masalah khusus yang digunakan untuk mengetahui pola sehingga ditemukan pedoman bersifat umum (Ma'moon, 2005). Sedangkan penalaran deduktif adalah kemampuan kesimpulan dari masalah yang bersifat umum menjadi bersifat khusus (Jujun S. Suriasumantri, 2007).

Soekadijo (1999) menyatakan bahwa induktif terdiri dari tiga jenis iaitu: generalisasi, analogi, dan sebab akibat. Penalaran induktif dalam penelitian ini adalah generalisasi dan analogi. Soekadijo (1999) mendefinisikan generalisasi ialah penalaran yang menurunkan kesimpulan yang bersifat umum dari premis berbentuk cadangan empirikal.Prinsip yang mendasari generalisasi induktif ialah "apa yang beberapa kali terjadi dalam kondisi tertentu, dapat diharapkan akan selalu terjadi apabila kondisi yang serupa dipenuhi”. Generalisasi membantu membentuk pola dan hubungan yang dapat digunakan untuk membangun pemahaman dan pengetahuan (Presmeg, Barrett, \& McCrone, 2007).

Penalaran analogi adalah metode pengolahan informasi yang membandingkan keserupaan antara konsep baru dan masa lalu yang dipahami, kemudian menggunakan keserupaan ini untuk mendapatkan pemahaman konsep baru (Voskoglou, 2012). Gentner (2003) menyatakan bahwa analogi adalah pemetaan pengetahuan dari satu domain (asas) ke dalam yang lain (sasaran). Penalaran analogi dalam pengajaran matematika diketahui dari ungkapan siswa pada benda konkrit dan diagram bergambar (English, 1997). Pengajaran melalui analogi biasanya meliputi penemuan hubungan antara sumber pengetahuan dengan tujuan/target (Mofidi, Amiripour, \& Zadeh, 2012). Dalam pendidikan, penalaran analogi adalah penting dalam pengajaran, seperti model dalam perpindahan pengetahuan baru, keadaan yang tidak dikenali (Mofidi, Amiripour, \& Zadeh, 2012). 


\section{Pendekatan Realistik}

$R M E$ yaitu suatu pendekatan yang memikirkan aktivitas manusia (Freudenthal, 1991; Gravemeijer, 1994; Treffers, 1987). Pendekatan matematika realistik merupakan suatu pendekatan dalam pembelajaran matematika yang berawal dari keadaan yang sebenarnya bagisiswa, menekankan kemampuan dalam proses matematika, berdiskusi dan berkerjasama dalam kelompok, bertukar pendapat dengan teman sebaya sehingga siswa dapat menemukan sendiri konsep matematika bukan pemberitahuan dari guru dan pada akhirnya menggunakan matematika untuk menyelesaikan masalah baik secara individu maupun dalam kelompok (Zulkardi, 2003).

Mulliset al. (2000) menyatakan bahwa Realistic Matematics Education (RME) dapat meningkatkan kemampuan matematika bukan saja bagi siswa yang pintar tetapi juga siswa yang lemah.Pembelajaran dengan menggunakan pendekatan Realistik Matematics Education $(R M E)$ dapat meningkatkan kemampuan penalaran matematika siswa secara signifikan lebih baik, dibandingkan kelompok siswa yang mengikuti pembelajaran tradisional (Kania, 2009). Melalui RME didapatkan siswa berfikir lebih aktif (Palinussa, 2013).

Pendapat lain menyatakan bahwa ada pengaruh penerapan pendekatan realistik terhadap penalaran matematik siswa (Mahayukti, 2004). Kemampuan berfikir matematika siswa yang belajar dengan menggunakan pendekatan matematika realistik ternyata lebih baik dibandingkan siswa yang belajar dengan menggunakan pendekatan tradisional (Saragih, 2007). Penerapan RME berpengaruh lebih baik daripada penerapan pembelajaran konvensional dalam hal kemampuan kemampuan kognitif siswa (Abidin, 2008). Pembelajaran dengan pendekatan realistik lebih baik dalam meningkatkan penalaran siswa dibandingkan dengan pendekatan biasa (ekspositori) (Manurung, 2009).

Lima kriteria dari RME (Gravemeijer, 1994; de Lange, 1987) yaitu: (1) penggunaan konteks (dunia nyata), (2) Penggunaan model dan Matematisasi, (3) penggunaan produksi dan kontribusi, (4) penggunaan interaktif, dan (5) penggunaan keterkaitan.

\section{Metode Penelitian}

Penelitian ini bertujuan untuk mengetahui efektifitas pendekatan realistik dalam kemampuan penalaran Matematika, dengan menggunakan metode eksperimen. Untuk metode penelitian eksperimen dipilih 2 kelompok siswa kelas 10 secara acak. Dari 2 kelompok siswa, satu kelompok dijadikan sebagai kelompok eksperimen dan yang satu lagi sebagai kelompok 
kontrol. Kelompok eksperimen diajar Matematika dengan menggunakan pendekatan realistik. Sedangkan kelompok kontrol tanpa realistik. Kelompok eksperimen dan kontrol diberikan ujian pra dan ujian pos. Penelitiaan ini menggunakan Randomized Pretest-Posttest Control Group Design yang diperkenalkan oleh Jack dan Norman (1993). Desain penelitian ini adalah seperti.

$\begin{array}{lllll}\text { Kelompok Eksperimen } & \mathrm{R} & \mathrm{O} & \mathrm{X}_{1} & \mathrm{O} \\ \text { Kelompok Kontrol } & \mathrm{R} & \mathrm{O} & \mathrm{X}_{2} & \mathrm{O}\end{array}$

Keterangan:

O: Pretes dan postes

$\mathrm{X}_{1}$ : Pembelajaran dengan pendekatan realistik

$\mathrm{X}_{2}$ : Pembelajaran tanpa pendekatan realistik

\section{Hasil Penelitian}

\section{$H_{a}(1)$ : Terdapat perbedaan yang signifikan pada kemampuan penalaran matematik antara siswa yang menggunakan pendekatan realistik dan yang tidak}

Uji Levene 'sdalam uji-t sampel bebas adalah tidak signifikan $(\mathrm{p}>.05)$. Keputusan ini telah memenuhi andaian kehomogenan varians yang sama antara siswa pada kelompok eksperimen dan kelompok kontrol. Uji-t berpasangan adalah signifikan $[\mathrm{t}(34)=-23.61, \mathrm{p}<$ .05] secara statistik. Rata-rata (26.09) ujian postes kemampuan penalaran matematika lebih tinggi dibandingkan dengan rata-rata (9.49) ujian pretes bagi siswa yang menggunakan pendekatan realistik. Demikian pula, median (26) ujian postes penalaran matematika lebih tinggi dibandingkan dengan median (5) ujian pretes. Ini menunjukkan peningkatan kemampuan penalaran matematik disebabkan karena penggunaan pendekatan realistik dalam pembelajaran matematika di SMAN 1 Tembilahan, Inhil, Riau. 


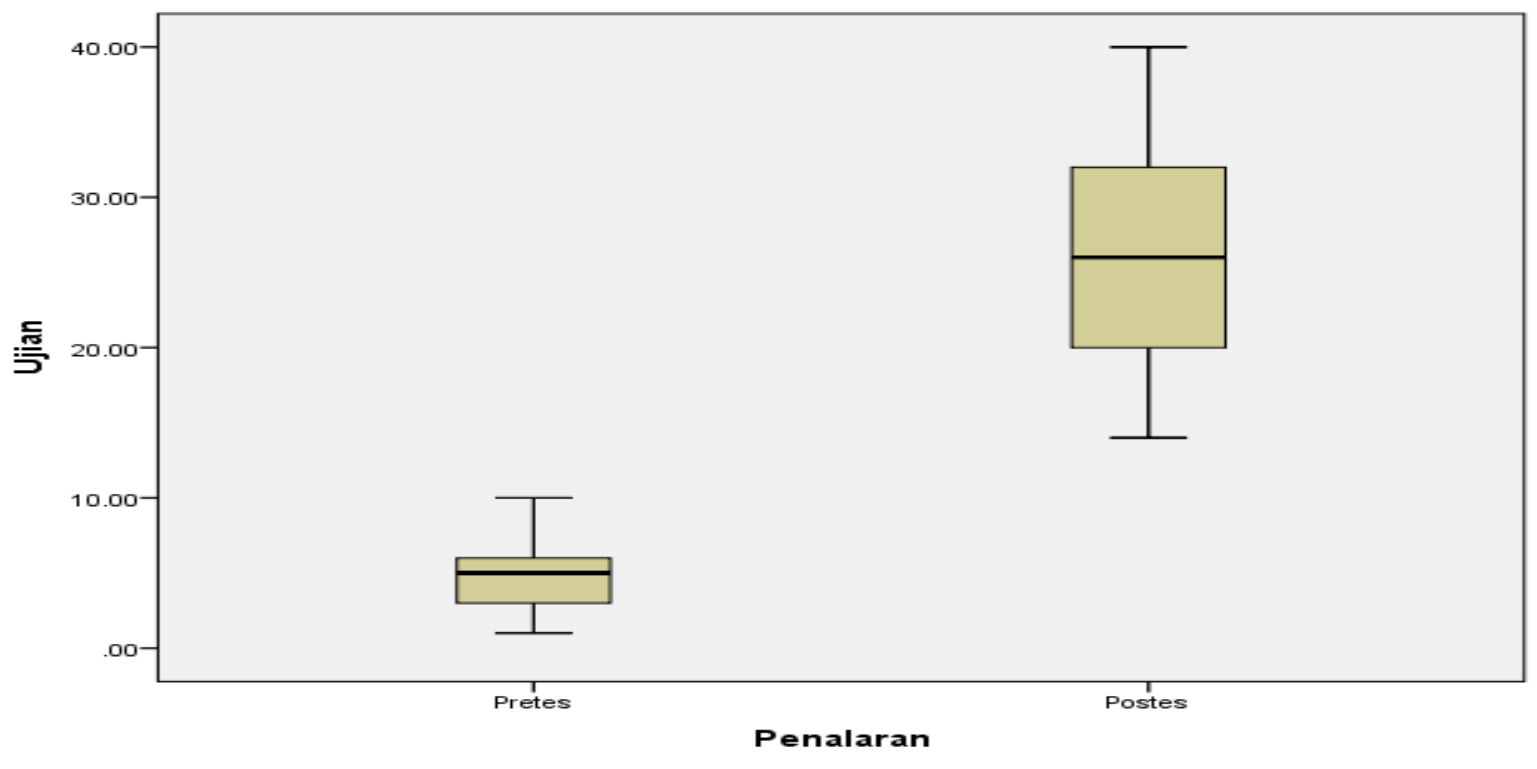

Gambarl. Kemampuan penalaran matematika bagi siswa yang menggunakan pendekatan realistik

\section{$H_{a}(2)$ : Terdapat perbedaan yang signifikan pada kemampuan penalaran analogi matematik antara siswa yang menggunakan pendekatan realistik dan yang tidak}

Uji-t berpasangan adalah signifikan $[\mathrm{t}(34)=-21.50, \mathrm{p}<.05]$ secara statistik. Ini menunjukkan terdapat perbedaan ujian pretes dan postes kemampuan penalaran analogi matematik dengan menggunakan pendekatan realistik. Rata-rata (13.60) ujian postes kemampuan penalaran analogi matematik lebih tinggi dibandingkan dengan rata-rata (1.63) ujian pretes bagi siswa yang menggunakan pendekatan realistik. Demikian pula, median (13) ujian postes kemampuan penalaran analogi matematik lebih tinggi dibandingkan dengan median (1) ujian pretes bagi siswa yang menggunakan pendekatan realistik.Ini menunjukkan peningkatan kemampuan penalaran analogi matematik disebabkan karena penggunaan pendekatan realistik dalam pembelajaran matematika.

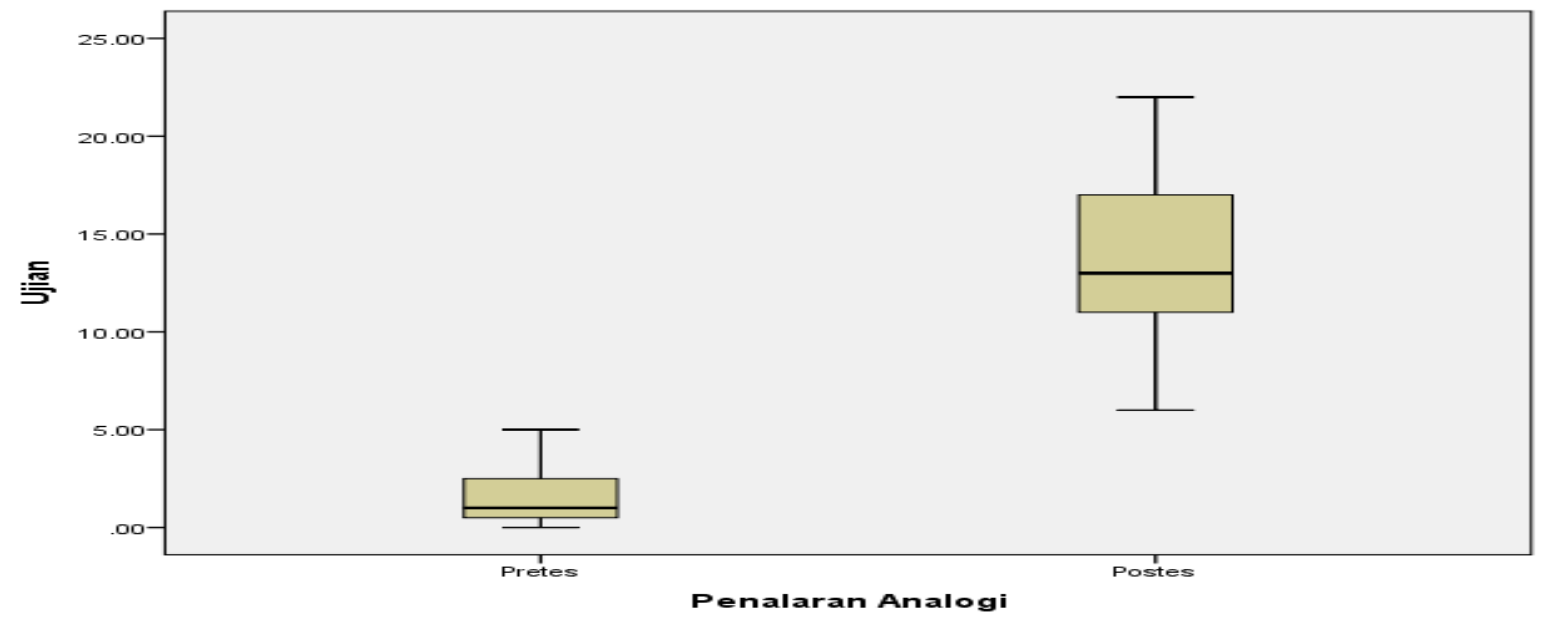


Gambar 2. Kemampuan penalaran analogi matematik bagi siswa yang menggunakan pendekatan realistik

\section{$H_{a}(3)$ : Terdapat perbedaan yang signifikan pada kemampuan penalaran generalisasi matematik antara siswa yang menggunakan pendekatan realistik dan yang tidak}

Uji-t berpasangan adalah signifikan $[\mathrm{t}(34)=-18.25, \mathrm{p}<.05]$ secara statistik. Rata-rata (12.49) ujian postes kemampuan penalaran generalisasi matematik lebih tinggi dibandingkan dengan rata-rata (3.14) ujian pretes bagi siswa yang menggunakan pendekatan realistik. Demikian pula, median (12) ujian postes kemampuan penalaran generalisasi matematik lebih tinggi dibandingkan dengan median (3) ujian pretes. Ini menunjukkan peningkatan kemampuan penalaran generalisasi matematik disebabkan karena penggunaan pendekatan realistik dalam pembelajaran matematika.

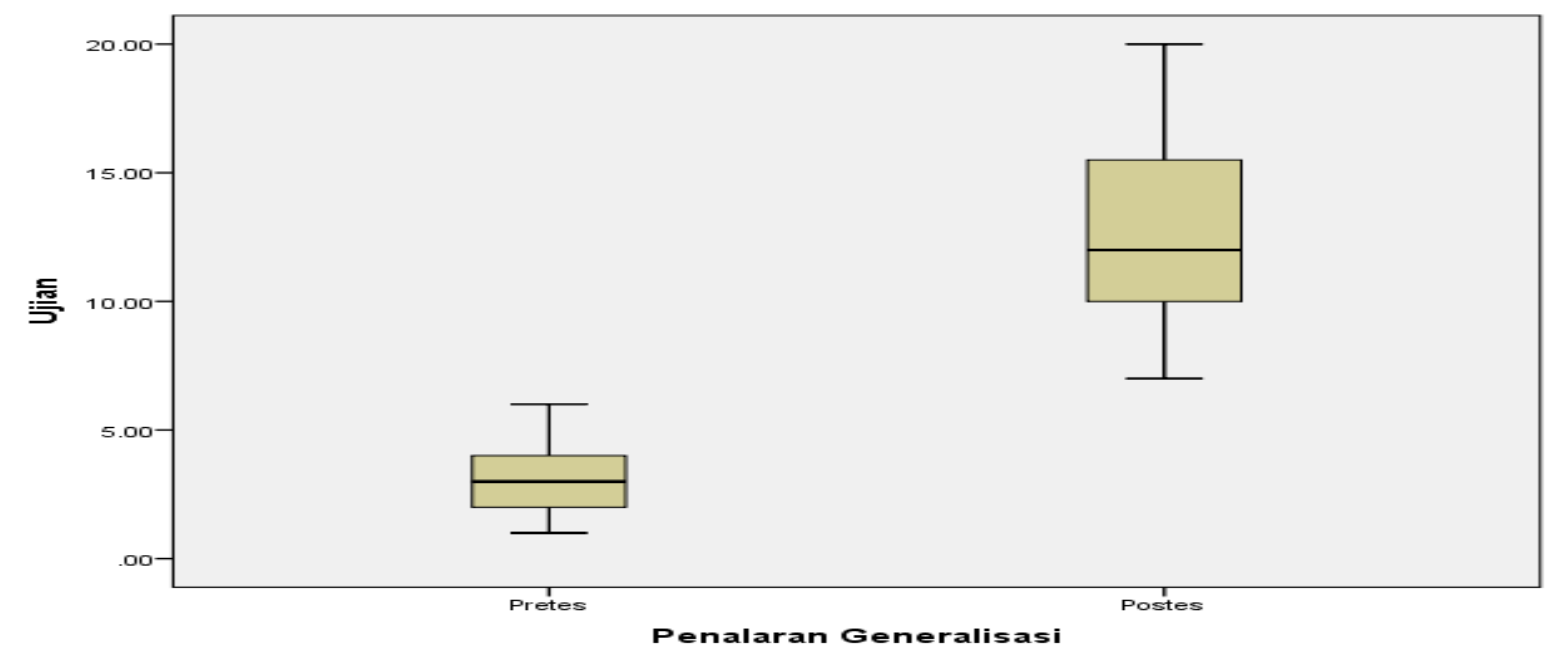

Gambar 3. Kemampuan penalaran generalisasi matematik bagi siswa dengan menggunakan pendekatan realistik

$H_{a}(4)$ : Terdapat perbedaan yang signifikan pada kemampuan penalaran matematik antara siswa yang menggunakan pendekatan realistik dan yang tidak

Uji-t sampel bebas adalah signifikan $[\mathrm{t}(67)=5.25, \mathrm{p}<.05]$ secara statistik bagi ujian postes kemampuan penalaran matematik antara siswa yang menggunakan pendekatan realistik dibandingkan tanpa realistik. Ini menunjukkan terdapat perbedaan kemampuan 
penalaran matematik antara siswa yang mengikuti pembelajaran dengan pendekatan realistik dibandingkan siswa yang mengikuti pembelajaran dengan pendekatan tanpa realistik. Dengan demikian, pendekatan realistik efektif dalam meningkatkan kemampuan penalaran matematik. Rata-rata (26.09) ujian postes kemampuan penalaran matematik siswa yang mengikuti pembelajaran dengan pendekatan realistik lebih tinggi dibandingkan rata-rata (17.59) ujian postes siswa tanpa realistik. Penggunaan peendekatan tanpa realistik hanya meningkatkan kemampuan penalaran matematik dari rata-rata (5.29) kepada rata-rata (17.59) yaitu perbedaannya sebanyak 12.30 (17.50 - 5.29). Sedangkan penggunaan pendekatan realistik dapat meningkatkan kemampuan penalaran matematik lebih tinggi yaitu dari ratarata (4.94) kepada rata-rata (26.09). Ini menunjukkan pendekatan realistik dalam pembelajaran matematik dapat meningkatkan penalaran matematik lebih tinggi dibandingkan pendekatan tanpa realistik yaitu perbedaannya sebanyak 21.15 (26.09 - 4.94) dibandingkan dengan perbedaan tanpa realistik sebanyak 12.30. Demikian pula, median (26) ujian postes kemampuan penalaran matematik siswa yang menggunakan pendekatan realistik lebih tinggi dibandingkan median (17) ujian postes siswa tanpa realistik.

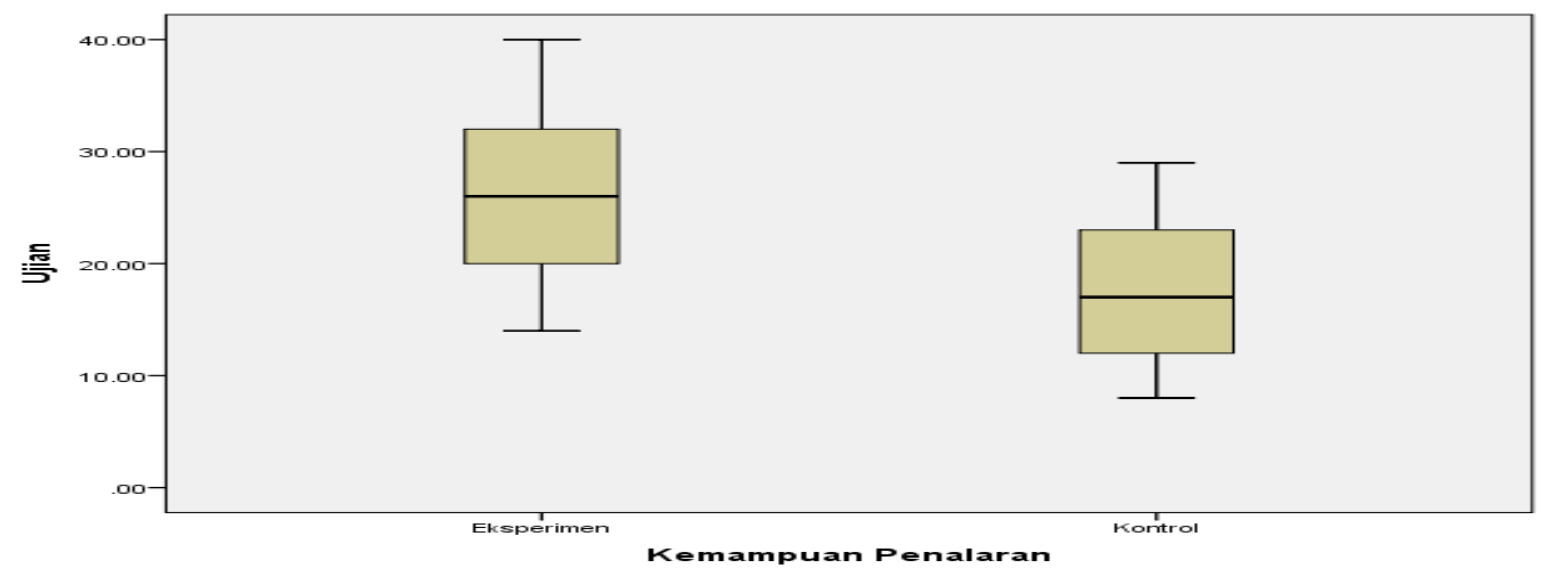

Gambar 4.Kemampuan penalaran matematik antara kelompok eksperimen dan kontrol

\section{Pembahasan dan Kesimpulan}

Pendekatan realistik efektif dalam meningkatkan kemampuan penalaran matematik siswa. Perihal ini senada dengan Mulliset al. (2000) menyatakan bahwa Realistic Matematics Education ( $R M E)$ dapat meningkatkan kemampuan matematika bukan saja bagi siswa yang kemampuan tinggi tetapi juga siswa yang lemah. Pendekatan realistik menggunakan dunia nyata sebagai sumber pembentukan konsep matematika. Penggunaan dunia nyata yang dipahami para siswa menjadikan proses pembelajaran matematika lebih bermakna, sehingga 
tujuan pendidikan matematika menjadi lebih baik dibandingkan masa lalu (Soedjadi, 2001, Februari).

Pendekatan matematika realistik merupakan suatu pendekatan dalam pembelajaran matematika yang diawali dari masalah yang dikenali oleh siswa (masalah kontekstual), sehingga memungkinkan siswa mengalami langsung proses pembelajaran (Zulkardi, 2003). Peranan konteks sangat penting dalam membuat model matematika, karena pembuatan model memerlukan suatu konteks untuk dijadikan kerangka masalah dalam mengkonstruksi konsep matematika (Mousoulides et al., 2007).

Pada awalnya siswa akan mengkonstruksi suatu model yang dikenalinya. Setelah proses formalisasi dan generalisasi, model itu setahap demi setahap menjadi satu dengan dirinya. Proses transisi ini di sebut model of ke model for. Proses transisi dari masalah kontekstual ke model of ataupun dari model of ke model for, disinilah peranan penalaran analogi matematik. Penalaran analogi matematik adalah metode pengolahan informasi yang membandingkan keserupaan antara konsep baru dan masa lalu yang dipahami, kemudian menggunakan keserupaan ini untuk mendapatkan pemahaman konsep baru (Voskoglou, 2012).

Penalaran analogi matematik didefinisikan secara umum sebagai perpindahan struktur informasi dari satu sistem sebagai asas kepada sistem lain sebagai target. Penalaran analogi matematik dalam pengajaran matematika diketahui dari ungkapan siswa pada benda konkrit dan diagram bergambar (English, 1997). Analogi berarti membandingkan dua hal yang berlainan berdasarkan keserupaannya, kemudian menarik kesimpulan atas dasar keserupaan tersebut. Gentner (2003) menyatakan bahwa analogi adalah pemetaan pengetahuan dari satu domain (dasar) ke dalam yang lain (sasaran).

Proses pembelajaran matematika dengan pendekatan realitik memberikan kesempatan kepada siswa untuk membangun penalaran matematik mereka. Dengan pendekatan realisik membuat siswa mampu menganalogikan masalah kontekstual dengan model of (bentuk informal), begitupula model of dengan model for. Dari model for ataupun model Matematika yang lebih formal, siswa mampu membuat langkah-langkah penyelesaian masalah matematika. Kemudian siswa mampu mencari pola untuk membuat generalisasi. Melalui generalisasi siswa mencari rumus yang dapat digunakan untuk menyelesaikan permasalahan lainnya.

Melalui RME siswa berfikir lebih aktif (Palinussa, 2013). Pendapat lain menyatakan bahwa ada pengaruh penerapan pendekatan realistik terhadap penalaran matematik (Mahayukti, 2004). RME ialah pendekatan yang potensial untuk pengajaran dan pembelajaran 
matematika berbeda dengan pendekatan tradisional. Banyak halangan yang dijumpai siswa ketika menggunakan pembelajaran tradisional berbeda dengan $R M E$ yang memberikan pengaruh positif pada proses belajar mengajar dan perubahan positif pada diri siswa terutama pada penalaran (Fauzan, Slettenhaar, \& Plomp, 2002).

Pembelajaran dengan menggunakan pendekatan Realistik Matematics Education $(R M E)$ dapat meningkatkan kemampuan penalaran matematik siswa secara signifikan lebih baik, dibandingkan kelompok siswa yang mengikuti pembelajaran tradisional (Kania, 2009). Begitu pula kemampuan penalaran analogi dan generalisasi matematik lebih baik bagi siswa yang mengikuti pembelajaran matematika dengan menggunakan pendekatan realistik dibandingkan tanpa realistik. Kemampuan berfikir matematik siswa yang belajar dengan menggunakan pendekatan matematika realistik ternyata lebih baik dibanding siswa yang belajar dengan menggunakan pendekatan tradisional (Saragih, 2007). Penerapan RME berpengaruh lebih baik daripada penerapan pembelajaran konvensional dalam hal kemampuan kognitif siswa (Abidin, 2008). Pembelajaran dengan pendekatan realistik lebih baik dalam meningkatkan penalaran siswa dibandingkan dengan pendekatan biasa (ekspositori) (Manurung, 2009).

Melalui pembelajaran matematika dengan pendekatan realistik terlihat perubahan positif pada diri siswa. Dalam pembelajaran siswa melalui sendiri proses penemuan konsep matematika. Pembelajaran diawali dari masalah kontekstual (kriteria RME, penggunaan konteks). Melalui pembuatan model, masalah-masalah kontekstual disusun dan dibentuk menjadi model matematika. Pembuatan model merupakan jambatan untuk mengubah masalah kontekstual menjadi pengetahuan formal. Dalam pembuatan model, siswa menggunakan model-model matematika yang telah diketahuinya (prinsip menggunakan model-model). Dengan bimbingan dan petunjuk yang diberikan guru secara terbatas, siswa dituntun sedemikian rupa sehingga siswa melalui proses penemuan kembali konsep matematika (prinsip penemuan terbimbing).

Dengan pendekatan realistik dalam pembelajaran memberikan kesempatan kepada siswa yang sangat leluasa untuk mencari sendiri konsep matematika. Menyelesaikan masalah kontekstual, memperkirakan langkah-langkah penyelesain masalah. Kemudian siswa mencari pola untuk membuat generalisasi dan menggunakan rumus matematika atau pun konsep matematika yang diketahui sebelumnya untuk menyelesaikan permasalahan yang lain berdasarkan kaedah matematika yang berlaku (kriteria penggunaan produksi dan konstribusi).

Pembelajaran matematik dengan pendekatan realistik lebih memberikan kesempatan kepada siswa untuk ikut serta secara langsung dalam menambah pengalaman belajarnya. 
Pendekatan realistik memunculkan sikap aktif dan kreatif siswa, terutama dalam menyelesaikan masalah yang diberikan, berdiskusi dengan teman dalam satu kelompok, sehingga siswa berani memberikan pendapat ataupun bertanya kepada guru. Keikutsertaan siswa secara langsung dalam proses pembelajaran menjadikan pembelajaran lebih bermakna dan menyenangkan sehingga efektifitas pembelajaran dapat tercapai (kriteria interaktif). Dengan demikian pendekatan realistik efektif dalam meningkatkan kemampuan penalaran matematika.

\section{Daftar Pustaka}

Abidin. (2008). Meningkatkan motivasi berprestasi, kemampuan pemecahan masalah dan hasil belajar siswa kelas IV SD melalui pembelajaran matematik realistik dengan strategi kooperatif (Disertasi Doktoral tidak diterbitkan). Universitas Pendidikan Indonesia, Bandung.

Ahmad F., Slettenhar, D., \& Plomp, T. (2002).Tradisional matematikaematics education vs realistic matematikaematics education.In P. Valero \& O. Skovsmose (Eds).Proceeding of The $3^{\text {rd }}$ Internasional Matematikaematics Education and Society Conference (pp. 1-4). Copenhagen: Centre for Research in Learning Matematics.

Arsaythamby, V., \& Rosna A. H. (2009). Kesahan dan kebolehpercayaan alat ukur orientasi pembelajaran Matematik (OPM). International Journal of Management Studies, 16(1), 57-73.

Brodie, K. (2010). Teaching matematical reasoning in secondary school classrooms. New York: Springer.

Budiyono. (2010). Peningkatan kualitas pembelajaran matematika melalui penilaian yang efektif. Diambil dari http://www.scribd.com/doc/21684083/Pengemb-MateriPembelaj-Budiono.

Cooper, B., \& Harries, T. (2002). Children's responses to contrasting 'realistic' matematikaematics problems: just how realistic are children ready to be? Educational Studies in Matematikaematics. 49 (1), 1-23.

Crouch, R., \& Haines, C. (2004). Matematikaematical modeling: trasitions between the real world and the matematikaematical model.International Journal of Matematikaematics Education in Science and Teknologi, 35 (2), 197 - 206.

Darhim. (2004). Pengaruh pembelajaran matematika kontekstual terhadap hasilbelajar dan sikap siswa sekolah dasar kelas awal dalam matematika. (Disertasi Doktoral tidak diterbitkan). Universitas Pendidikan Indonesia, Bandung.

De Lange. (1987). Matematikaematics insight and meaning.Utrecth: Rijkuniversiteit.

De Lange. (1998). Using and applying matematikaematics in education: International Handbook of Matematikaematics Education. London: Kluwer Academic Publisher.

Diezmann, C. M. (2004).The role of operating premises and reasoning paths in uppper elementary students' problem solving.Journal of Matematikaematical Bahavior.23 (1), 63-73.

Diezmann, C. M., Watters, J. J., \& English, L. D. (2002).Teacher behaviours that influence young children's reasoning. In A. D.Cockburn \& E. Nardi (Eds.),Proceedings $27^{\text {th }}$ 
Annual Conference of the International Group for the Psychology of Matematikaematics Education 2 (pp. 289-296). UK: Norwich.

Djaali. (2008, Julai 25). Ubah cara pengajaran matematika. Harian Umum Kompas. Diambil dari http://aingkumaha.blogspot.com/2008/07/ubah-cara-pengajaran matematika.html.

Dolk, M., Sutarto H., \& Sembiring, R. K. (2008).Reforrata-ratag Matematikaematics learning in Indonesia classrooms through RME.ZDM Matematikaematics Education, 40, 927-939. doi:10.1007/s11858-008-0125-9.

Edy. (2008, Julai 25). Ubah cara pengajaran matematika. Harian Umum Kompas. Diambil dari http://aingkumaha.blogspot.com/2008/07/ubah-cara-pengajaranmatematika.html.

English, L. D. (1997). Matematikaematical reasoning, analogies, metaphors, and images .New Jersey: Lawrence Erbaum Associates, Inc.

Erich, C. W. (2005). Realistic matematikaematics education, past and present. Dortmund: Universitat Dortmund.

Erman S., Turmudi, Didi S., Tatang H., Suhendra, Susyani P., Nurjanah, \& Ade R. (2003). Strategi pembelajaran Matematika kontemporer. Bandung: UPI.

Fajar S. (2004, Ogos). Penalaran, pemecahan masalah, dan komunikasi dalam pembelajaran Matematika. Paper yang dipresentasikan pada Diklat Instruktur Matematika SMP Jenjang dasar PPPG Matematika, Yogjakarta.

Freudenthal, H. (1991). Revisiting matematikaematics education: china lectures. Dordrecht: Kluwer Academic Publishers.

Gentner, D. (2003). Analogical reasoning, psychology of. In Encyclopedia of Cognitive Science (pp. 106-112). London: Nature Publishing Group.

Gravemeijer, K. (1994). Developing realistic matematikaematics education.Utrecht: CD-b Press.

Hasratuddin. (2010). Meningkatkan kemampuan berpikir kritis siswa SMP melalui pendekatan matematika realistik. Jurnal Pendidikan Matematika, 4(2), 19-33.

Heinze, Aiso, \& Kwak, Jee Yi. (2002). Informal prerequisites for informal proofs. The International Journal on Matematikaematics Education, 34 (1), 9-16.

Herman. (2007). Pembelajaran berbasis masalah untuk meningkatkan kemampuan penalaran matematis siswa SMP. Cakrawala Pendidikan, 26(1), 41-62.

Husen W. (2007). Pembelajaran matematik realistik dalam meningkatkan kemampuan berfikir logis, kreatif dan kritis, serta komunikasi Matematik siswa Sekolah Dasar. Jurnal Pendidikan Dasar, 1(8), 1-4.

Ifada N. (2007). Realistic Matematikaematics Education (RME): pendekatan pendidikan Matematika dalam konsep dan realitas. Jurnal Pemikiran Alternatif Pendidikan Insania, 12 (1), 93-106.

Isjoni. (2007). Saatnya pendidikan kita bangkit Yogyakarta: Pustaka Siswa.

Iwan P. (2011, Januari 31). Mau di bawa kemana matematika kita?. Harian Kompas. Diambil dari

http://edukasi.kompas.com/read/2011/01/31/20092036/Mau.Dibawa.Kemana.Mate matika.Kita.

Jack, R. F., \& Norman E. W. (1993). How to design and evaluate research in education. New York: Mc Graw-Hill.

Jenings, S., \& Dunne, R. (1999).Matematika stories, real stories, real-life stories. Diambil dari www.ex.ac.uk/telematics/T3/matematikas/matematikafram.htm.

Jujun S. S. (2007). Filsafat ilmu sebuah pengantar populer. Jakarta: Pusataka Sinar Harapan. 
Kadir. (2009, Desember). Kemampuan komunikasi matematik siswa SMP di daerah Pesisir Kabupaten Buton setelah mendapat pembelajaran kontekstual.Paper dipresentasikan pada Serata-rataar Pendidikan Matematika Jurusan MIPA UNY, Yogyakarta.

Kamaliyah, Zulkardi, \& Darmawijoyo. (2013). Developing the sixth level of PISA-like Matematikaematics problems for secondary school students. Indonesia Matematikaematics Society Journal on Matematikaematics Education (IndoMS. J.M.E), 4(1), 9-28.

Kania. (2009). Kegiatan pembelajaran realistic matematikaematics education (RME) sebagai upaya meningkatkan kemampuan penalaran dan komunikasi Matematika siswa Sekolah Dasar. (Tesis Magister tidak diterbitkan) Universitas Pendidikan Indonesia, Bandung.

Lee, Kyung Hwa., Kim, Rata-rata Jung., GwiSoo Na., Han, DaeHee., \& Song, SangHun.(2007). Induction, analogy, and imagery in geometric reasoning.In Woo, J. H., Lew, H. C., Park, K. S., \& Seo, D. Y (Eds.),Proceedings of the $31^{\text {st }}$ Conference of the International Group for the Psychology of Matematikaematics Education (pp. 145-152). Seoul: PME.

Leonard. (2008). Pengaruh konsep diri, sikap siswa terhadap hasil belajar Matematika (survei pada SMP di Wilayah DKI Jakarta).Diambil dari http://www.namadomain.com/ndban biq.qif.

Lindsey, E. R., Osnat, Z., \& Keit, J. H. (2007). Cognitive supports for analogies in the Matematikaematics classroom.Education Forum Matematikaemaitcs. Diambil dari www.sciencemag.org.

Ma'moon. (2005). Matematikaematical thingking and Matematikaematics achievement of studies in year 11 scientifics stream in Jordan. (Unpublish Doctoral Disertation). Faculty of Education and Arts the University, New Castle.

Maas, K. (2006). What are competencies. University of Education Freiburg: ZDM, 38(2), 113 -141 .

Mahayukti. (2004). Pengaruh penerapan pendekatan realistik terhadap penalaran dan komunikasi Matematik siswa SLTP 1 Singaraja.Jurnal Pendidikan dan Pengajaran IKIP Singaraja, 37 (3), 29-39.

Manurung, B. (2009). Meningkatkan kemampuan penalaran formal dalam pembelajaran Matematika SMP dengan pendekatan pembelajaran Matematika realistik. (Tesis Magister tidak diterbitkan). Universitas Sumatera Utara, Medan.

Marpaung. (2001, Februari).Prospek RME untuk pembelajaran Matematika di Indonesia. Paper dipresentasikan pada Serata-rataar Nasional Realistic Matematikaemati $c$ Education di FMIPA UNESA, Surabaya

Matlin. (1994). Cognition. Orlondo: Hardcourt Publisher.

Mofidi, S. A., Amiripour, P., \& Zadeh, M. H. B. (2012).Instruction of Matematikaematical concepts through analogical reasoning skills.Indian Journal of Science and Technology, 5(6), 2916-2922.

Mousoulides, N., Sriraman, B., \& Christou, C. (2007).From problem solving to modeling-the emergence of models and modelling perspectives. Nordic Studies in Matematikaematics Education, 12 (1), 23-47.

Muhammad N. (2013, Mei 23). Mendikbud umumkan hasil akhir UN SMA 2013. Antara New. Diambil dari http://www.antaranews.com/berita/376294/mendikbudumumkan-hasil-akhir-un-sma-2013.

Mullis, I. V. S, Martin, M. O., Gonzalez, E.J., Gregory, K.D., Garden, R.A., O’Connor, K. M., Chrostowski, S. J., \& Smith, T. A. (2000). TIMSS 1999 Internasional matematikaematics science refort finding from IEA's repeat of the third 
international matematikaematics and science study at the eighth grade. International Study Center Boston College, Lynch School of Education.

Nik A. N. P. (2008). Isu-isu kritikal dalam pendidikan Matematik. Kuala Lumpur: Universiti Malaya.

Ondi S. \& Siti K. (2009). Korelasi penggunaan model pembelajaran klasikal dengan kemampuan penalaran analogi Matematika siswa (Studi KasusPada Siswa Kelas VIII SMP N I Gegesik Kabupaten Cirebon).EduMa, 1(1), 17 - 24.

Ondi S. (2008). Menumbuhkembangkan berfikir logis dan sikap positif terhadap Matematika melalui pendekatan Matematika realistik.Equilibrium, 4(8), 86 - 95.

Palinussa, A. L. (2013). Students' critical matematikaematical thinking skills and character: experiments for junior high school students through eealistic matematikaematicseducation culture-based. Indonesia Matematikaematical Society Journal on Matematikaematics Education (IndoMS. J.M.E.), 4 (1), 75-94.

Presmeg, N., Barrett, J., \& McCrone, S. (2007). Fostering generalization in connecting registers of dynamic geometry and euclidean constructions. In J. H.Woo., H. C. Lew., K. S. Park., \& D. Y. Seo. (Eds.), Proceedings of the 31st Conference of the International Group for the Psychology of Matematikaematics Education (pp. 8188). Seoul: PME.

Saragih, S. (2007). Mengembangkan kemampuan berfikir logis dan komunikasi matematiksiswa sekolah menengah pertama melalui pendekatan Matematika realistik. (Tesis Master tidak diterbitkan). Universitas Pendidikan Indonesia, Bandung.

Soedjadi, R. (2001, Februari). Pembelajaran Matematika realistik: pengenalan awal dan praktis. Paper dipresentasikan pada serata-rataar Nasional di FMIPA UNESA, Surabaya.

Soekadijo. (1999). Logika dasar tradisional, simbolik dan induktif. Jakarta: Gramedia.

Somakin. (2007, Nopember).Pengembangan berpikir matematika tingkat lanjut melalui pembelajaran matematika realistik. Paper dipresentasikan pada Serata-rataar Nasional Pendidikan Matematikadi Universitas Negeri, Yogyakarta.

Sri E., Yusuf H., \& Ratu P. (2013). Investigating secondary school students' difficulties in modeling problems PISA-model level 5 And 6. Indonesia Matematikaematical Society Journal on Matematikaematics Education (IndoMS. J.M.E), 4 (1), 41-58.

Suharta. (2003). Pendidikan Matematika Realistik Indonesia (alternatif pembelajaran Matematika yang berorientasi Kurikulum Berbasis Kompetensi). Jurnal Pendidikan dan Pengajaran IKIP Negeri Singaraja, 36, 137-155.

Sumadi. (2005). Pengaruh penerapan pendekatan kontekstual terhadap kemampuan penalaran dan komunikasi Matematika siswa kelas II SLTP Negeri 6 Singaraja. Jurnal Pendidikan dan Pengajaran IKIP Negeri Singaraja, 38(1), 1-16.

Sutarto H. (2002). Effetive teacher professional development for the implementation of realistik matematikaematics education in Indonesia. (Unpublish Doctoral Disertation). Univertsity of Twente, Enschede.The Netherlands.

Sutarto H. (2005). Pendidikan matematika realistik dan implementasinya. Banjarmasin: Tulip.

Sutarto H. (2012, Julai). Matematikaematics education reform movement in Indonesia.Paper presented $12^{\text {th }}$ International Congress on Matematikaematical Education Program Name XX-YY-zz COEX, Seoul, Korea.

Tekin, A., Kula, S., Hidiroglu, C.N., Guzel, E.B., \& Ugurel, I, (2011, Julai). Deterratarataing the views of matematikaematics student teachers related to matematikaematical modelling. This paper is made up of an improved version of the poster presentation presented at the 35th Conference of the International Group for 
the Psychology of Matematikaematics Education, Middle East Technical University, Ankara, Turkey.

TIMMS., \& PIRLS. (2003). Trend in international matematikaematics and science study, International Study Centre, Lynnch School of Education, Boston College. Diambil dari http://timss.bc.edu/PDF/to3_download/To3_M_Chap1.pdf.

TIMMS., \& PIRLS. (2007). Trend in international matematikaematics and science study, International Study Centre, Lynnch School of Education, Boston College.Diambil dari http://timss.bc.edu/timss 2007/intl_reports.html.

TIMMS., \& PIRLS. (2011). Trend in international matematikaematics and science study, International Study Centre, Lynnch School of Education, Boston College.Diambil dari http://timssandpirls.bc.edu/timss2011/international-resultsmatematikaematics.html.

TIMSS. (1999). International student achievement in Matematikaematics. Diambil dari http://timss.bc.edu/timss matematika 01.pdf.

Treffers, \& Gofree. (1995). Rational analysis of realistic matematikaematics education - the wiskobas program.In L. Streefland. (Eds.), Proceedings of the Ninth International Conference for the Psychology of Matematikaematics Education (pp.97-121). The Netherlands: Noordwijkerhout.

Treffers. (1987). Three Dimension. A Model of Goal and Theory Description in Matematikaematic Instruction - the Wiskobas Project. Dordrecht: Reidel Publishing Company.

Turmudi. (2009). Students' responses to the realistic matematikaematics teaching approach in junior secondary school in Indonesia. In Proceeding of Indo MS International Conference on Matematikaematics and Its Application (IICMA) (pp. 1-15). Yogjakarta: Indonesia Matematikaematical Society (IndoMS).

Utari S. (2010). Berpikir dan disposisi Matematik: Apa, mengapa, dan bagaimana dikembangkan pada peserta didik. Artikel pada FPMIPA UPI Bandung. Diambil dari http://matematika.sps.upi.edu/?p=58.

Voskoglou, M. (2012). A fuzzy model for analogical problem solving. International Journal of Fuzzy Logic Systems (IJFLS), 2 (1), 1-10.

Wahyuddin. (1999). Kemampuan guru Matematika, calon guru Matematika, dan siswa dalam mata siswaan Matematika. (Disertasi Doktoral tidak diterbitkan). Universitas Pendidikan Indonesia, Bandung.

Wina S. (2006). Pembelajaran dalam implementasi Kurikulum Berbasis Kompetensi. Jakarta: Kencana.

Yanto P. \& Utari S. (2007). Mengembangkan kemampuan penalaran dan koneksi Matematik siswa SMA melalui pembelajaran berbasis masalah.Educationist, 1(2), 116-123.

Yuliani. (2006). Faktor-faktor yang mempengaruhi kinerja guru Matematika dalam pelaksanaan kurikulum berbasis kompetensi (KBK) pada Sekolah Menengah Atas Kota Palembang. Jurnal Manajemen \& Bisnis Sriwijaya, 4(7), 1-18

Zulkardi. (2002). Development a Learning environment on Realistic Matematikaematics Education (RME) for Indonesian student teachers. (Unpublish Doctoral Disertation). University of Twente, Enschede.The Netherlands.

Zulkardi. (2003). Peningkatan mutu pendidikan matematika melalui mutu pembelajaran. Dalam Buletin PMRI (Pendidikan Matematika Realistik Indonesia). 1, 1-3

Zulkardi \& Nieveen, N. (2001, Ogos). CASCADE-IMEI: Web site support for student teacherslearning Realistic Matematikaematics Education (RME) in Indonesia. Paper presented in theICTMT5 conference, Klagenfurt, Austria. 
Zulkardi. Nieveen, N., van den Akker, J., \&de Lange, J. (2002). Designing, evaluating and implementing an innovative learning environment for supporting Matematikaematics Education reform in Indonesia: The CASCADE-IMEI study. In P. Valero \& O. Skovsmose (Eds.), Proceedings of the $3^{\text {rd }}$ International Matematikaematics Educationand Society Conference (pp. 1-5). Copenhagen: Centre for Research in Learning Matematikaematics. 